\begin{tabular}{|l|l|l||}
\hline \multicolumn{2}{|c|}{ PublisherInfo } \\
\hline \hline PublisherName & $:$ & BioMed Central \\
\hline \hline PublisherLocation & $:$ & London \\
\hline \hline PublisherImprintName & $:$ & BioMed Central \\
\hline \hline
\end{tabular}

\title{
Mammary pathology of genetically engineered mice
}

\begin{tabular}{|l|l|l||}
\hline \multicolumn{2}{|c||}{ ArticleInfo } \\
\hline \hline ArticleID & $:$ & 3703 \\
\hline \hline ArticleDOI & $:$ & $10.1186 /$ bcr-2000-66666 \\
\hline \hline ArticleCitationID & $:$ & 66666 \\
\hline \hline ArticleSequenceNumber & $:$ & 69 \\
\hline \hline ArticleCategory & $:$ & Paper Report \\
\hline ArticleFirstPage & $:$ & 1 \\
\hline \hline ArticleLastPage & $:$ & 4 \\
\hline \hline & $:$ & RegistrationDate : 2000-4-5 \\
ArticleHistory & $:$ & OnlineDate \\
\hline \hline ArticleCopyright & $:$ & Current Science Ltd2000-4-5 \\
\hline \hline ArticleGrants & $:$ & \\
\hline \hline ArticleContext & $:$ & 1305822 \\
\hline \hline
\end{tabular}




\section{Keywords}

Annapolis, breast tumor classifications, genetically engineered mice

\section{Introduction}

Nearly 100 strains of genetically engineered mice that produce mammary tumors now exist with many more on the way. It is unclear whether many of the GEM are, in fact, suitable models for human breast cancer. This is due to a lack of detailed tumor pathology analysis as well as a failure to make comparisons to human tissues. This article compares the pathology and classification of mouse and human breast cancers.

\section{Aims}

To provide a reference for the accurate pathological analysis of mammary lesions in GEM in order to close the gap that now exists between morphologic and molecular biology.

\section{Comments}

This paper should be required reading for all mammary gland biology and breast cancer researchers who use or are planning to use the mouse as a model for breast cancer. A comparison by nine pathologists of a comprehensive collection of mammary lesions that have arisen in genetically engineered mice (GEM) is summarized. In order to standardize pathological techniques throughout the research community, detailed guidelines for specimen collection and fixation and for reporting on mammary lesions are described. Accurate pathological analysis of lesions in GEM is needed to understand these models. 


\section{Methods}

Nine medical and veterinary pathologists independently reviewed slides representing 39 models of GEM which were donated from around the world. In addition, two rat models, three transplant models, two chemical carcinogenesis models and three MMTV-induced tumors were also examined.

\section{Results}

A historical background to the nomenclature of mouse mammary tumors is provided. A classification system for GEM mammary lesions is described and tabulated. Morphological descriptors for GEM neoplasms are provided accompanied by examples, including glandular, acinar, cribiform, papillary, solid, squamous, fibroadenoma, adenomyoepithelioma and adenosquamous patterns. Modifiers, terms that provide additional information about the descriptor, are outlined and illustrated. Figures for modifiers such as carcinoma, adenocarcinoma, adenoma, and mammary intraepithelial neoplasia (MIN) are included. These modifiers imply the knowledge of the biological behavior of a lesion. Other modifiers describe the cell or tissue properties, such as atypia, necrosis, fibrosis, secretory, and metaplasias these are described and examples indicated. Typical phenotypes for MMTV-induced, chemically-induced, c-erb-2/neu, myc, ras, and ret-1 tumors are shown. Criteria for malignancy are outlined. Classification of lesions into non-GEM tumors, GEM tumors, GEM signature tumors, GEM tumors that mimic human tumors, and multigenic GEM tumors is explained.

\section{Discussion}

The Annapolis panel has made several recommendations. The use of a morphology-based nomenclature to describe mammary lesions in GEM is advised, later to be replaced by a "clinical" classification once the natural history of mammary lesions is better understood.

Detailed comparative studies of human and mouse lesions are needed to determine how they are related.

Standardized procedures should be used in sampling, collection, processing, and reporting on GEM lesions.

An experienced mammary pathologist should be a part of every study using mouse as a model for human breast cancer. 


\section{Additional information}

The Interactive Histology Atlas displays over 800 annotated images of GEM mammary lesions and human breast cancers. An interactive CD-ROM is being made and will be made available to the research community.

\section{References}

1. Andrechek ER, Hardy WR, Siegel PM, Rudnicki MA, Cardiff RD, Muller WJ: The mammary pathology of genetically engineered mice: the consensus report and recommendations from the Annapolis meeting. Oncogene. 2000, 19: 968-988. 